\title{
Role of extracorporeal membrane oxygenation in children with sepsis: a systematic review and meta-analysis
}

\author{
Kollengode Ramanathan ${ }^{1,2^{*}}$ (D) Nicholas Yeo ${ }^{3}$, Peta Alexander ${ }^{4,5}$, Lakshmi Raman ${ }^{6}$, Ryan Barbaro ${ }^{7}$, \\ Chuen Seng Tan², Luregn J. Schlapbach ${ }^{8,9}$ and Graeme MacLaren ${ }^{1,2}$
}

\begin{abstract}
Background: The benefits of extracorporeal membrane oxygenation (ECMO) in children with sepsis remain controversial. Current guidelines on management of septic shock in children recommend consideration of ECMO as salvage therapy. We sought to review peer-reviewed publications on effectiveness of ECMO in children with sepsis.

Methods: Studies reporting on mortality in children with sepsis supported with ECMO, published in PubMed, Scopus and Embase from 1972 till February 2020, were included in the review. This study was done in adherence to Preferred Reporting Items for Systematic Review and Meta-Analysis statement after registering the review protocol with PROSPERO. Study eligibility was independently assessed by two authors and disagreements resolved by a third author. Publications were reviewed for quality using Grading of Recommendations Assessment, Development, and Evaluation (GRADE) system. Random-effects meta-analyses (DerSimonian and Laird) were conducted, and 95\% confidence intervals were computed using the Clopper-Pearson method. Outliers were identified by the Baujat plot and leave-one-out analysis if there was considerable heterogeneity. The primary outcome measure was survival to discharge. Secondary outcome measures included hospital length of stay, subgroup analysis of neonatal and paediatric groups, types and duration of ECMO and complications.
\end{abstract}

Results: Of the 2054 articles screened, we identified 23 original articles for systematic review and meta-analysis. Cumulative estimate of survival (13 studies, 2559 patients) in the cohort was 59\% (95\%Cl: 51-67\%). Patients had a median length of hospital stay of 28.8 days, median intensive care unit stay of 13.5 days, and median ECMO duration of $129 \mathrm{~h}$. Children needing venoarterial ECMO (9 studies, 208 patients) showed overall pooled survival of $65 \%$ (95\% $\mathrm{Cl}$ : 50-80\%). Neonates (< 4 weeks of age) with sepsis needing ECMO (7 studies, 85 neonates) had pooled survival of 73\% (95\%Cl: 56-87\%). Gram positive organisms were the most common pathogens (47\%) in septic children supported with ECMO.

Conclusion: Survival rates of children with sepsis needing ECMO was 59\%. Neonates had higher survival rates (73\%); gram positive organisms accounted for most common infections in children needing ECMO. Despite limitations, pooled survival data from this review indicates consideration of ECMO in refractory septic shock for all pediatric age groups.

Keywords: Pediatric, Neonatal, Sepsis, Septic shock

*Correspondence: ram_ramanathan@nuhs.edu.sg

${ }^{1}$ Cardiothoracic Intensive Care Unit, Department of Cardiothoracic Surgery, National University Hospital, Singapore 119228, Singapore Full list of author information is available at the end of the article

\section{Background}

Sepsis and septic shock remain an important cause of childhood mortality globally despite advances in early detection and appropriate management in Intensive original author(s) and the source, provide a link to the Creative Commons licence, and indicate if changes were made. The images or other third party material in this article are included in the article's Creative Commons licence, unless indicated otherwise in a credit line to the material. If material is not included in the article's Creative Commons licence and your intended use is not permitted by statutory regulation or exceeds the permitted use, you will need to obtain permission directly from the copyright holder. To view a copy of this licence, visit http://creativecommons.org/licenses/by/4.0/. The Creative Commons Public Domain Dedication waiver (http://creativeco mmons.org/publicdomain/zero/1.0/) applies to the data made available in this article, unless otherwise stated in a credit line to the data. 
Care Units (ICUs) [1]. The World Health Assembly, the decision-making body of the World Health Organisation, adopted a recent resolution to reduce the global burden of sepsis through early identification, prevention and management [1-5]. The percentage of all global deaths in 2017 related to sepsis was highest in neonates and children compared to the adult population [5]. A recent systematic review revealed that nearly 1 in 4 children with sepsis die. Children most at risk of death are younger patients and those with septic shock; sepsis and infections account for 6.3 deaths of 1000 live births among children younger than 5 years [6].

While current best practice includes the early delivery of sepsis treatment bundles, therapeutic options for children refractory to initial resuscitation remain very limited [7]. The development of refractory shock is associated with a steep increase in mortality in pediatric sepsis [8-11]. Previous sepsis guidelines, including the American College of Critical Care Medicine, recommended consideration for Extracorporeal Membrane Oxygenation (ECMO) for persistent shock in spite of early fluid- and inotrope-based resuscitation [12, 13]. Studies have reported an increase in use of ECMO for pediatric septic shock with improving outcomes over time [14-17]. Survival rates of septic patients supported with ECMO are above $70 \%$ for neonates $[16,18,19]$ and approximately $40 \%$ for older children in both single centre and registry studies. Accordingly, the 2020 Surviving Sepsis Campaign International Guidelines for the Management of Septic Shock and Sepsis-Associated Organ Dysfunction in Children recommended venoarterial ECMO as rescue therapy in children with septic shock only if refractory to all other treatments, with a low level of evidence and a weak recommendation [20].

These recommendations remain based on few, relatively small studies. Additional challenges relate to the difficulties in assessing outcomes in heterogeneous cohorts of critically ill children and the number of factors which may contribute to outcomes, including patient selection, time to ECMO initiation, cannulation strategies, different ECMO technology, and the experience of the treating team $[17,21]$. As a result, the outcome benefits of ECMO in pediatric sepsis remain controversial. We sought to systematically review the literature to examine survival rates of pediatric and neonatal patients with sepsis needing ECMO, and to describe etiologies of sepsis and the complication rates in published cohorts of neonates and children treated with ECMO for sepsis.

\section{Methods}

This study was done in adherence to the ethical guidelines stated in the Declaration of Helsinki following the Preferred Reporting Items for Systematic Review and
Meta-Analysis (PRISMA) statement. [22] The review protocol was registered with PROSPERO (Ref:CRD 42020161828).

\section{Study selection}

A comprehensive literature search was performed using MEDLINE, Embase and Scopus databases to retrieve published data from 1972 up to $15^{\text {th }}$ February 2020 on the use of ECMO in neonatal and pediatric septic patients. The search phrases for the three databases included Boolean terms 'AND' and 'OR' with the following keywords in various possible combinations: "ECMO", "extracorporeal membrane oxygenation", "ECLS", "Infant", "newborn", "neonatal", "pediatric", "sepsis", and "infection" [Additional file 1: eTable 1]. In addition, a hand search of all relevant studies and their citation lists was performed to identify additional articles for inclusion. Articles were selected for systematic review if they described neonatal and/or pediatric septic patients undergoing venoarterial and venovenous ECMO and the incidence of mortality was clearly stated. No restriction was placed on study type (prospective or retrospective). For studies that included overlapping patients (period of overlap $>1$ year), the largest study was included in the meta-analysis while the rest of the studies were included in the review. We excluded studies with predominantly patients above 18 years old, articles with fewer than 5 patients, articles not written in English, conference abstracts, surveys and articles without full text, review articles and case reports. Publications from the Extracorporeal Life Support Organization (ELSO) International registry were excluded since data on patients reported to the ELSO Registry are likely also reported to national databases and present in single center reviews and thus potentially duplicated. Studies based on national registers were included provided there was no overlap with single-center studies. The eligibility of studies was independently assessed by two review authors (NY and KR) and disagreements were resolved by consensus or appeal to a third author (GM). Publications were reviewed for quality using the Joanna Briggs Institute (JBI) checklist for prevalence studies [23] as well as the Grading of Recommendations Assessment, Development, and Evaluation (GRADE) system to the determine the overall rating confidence in the body of evidence [24]. Case reports and case series ( $<5$ patients) were excluded due to likelihood of positive outcome bias.

\section{Study analysis}

Data including study design, outcomes, patient characteristics, and interventions were extracted independently. Neonates were defined as children 28 days or less of age. Descriptive statistics, such as the medians and 25th to 
75th percentiles were reported for continuous variables, and the counts and percentages were reported for categorical variables. Survival to discharge was the primary measure of outcome in our meta-analysis. Secondary outcome measures included hospital length of stay, types and duration of ECMO and complications. Subgroup analysis were also performed for the neonatal and pediatric age group.

We anticipated heterogeneity between studies. To account for the variability between studies in the metaanalysis, we used the random-effects model that was based on the inverse variance method where the DerSimonian and Laird method [25] was used to estimate the between-study variance. Briefly for the meta-analysis of proportions, exact confidence interval $(\mathrm{CI})$ for each proportion was computed using the Clopper-Pearson method [26]. A variance-stabilizing transformation, called the Freeman-Tukey double arcsine transformation [27], was applied to all proportions and the meta-analysis was performed on the transformed proportions. The pooled transformed proportion and its $95 \% \mathrm{CI}$ were back transformed to obtain pooled estimates on the original proportion scale. To obtain a pooled mean age of study participants across studies, studies that did not report the mean and/or its corresponding standard deviation (SD) had these quantities estimated from the reported medians, range, and IQR using the methods proposed by Wan et al. [28].

Statistical heterogeneity between studies was identified using $\mathrm{I}^{2}$ statistics, where $\mathrm{I}^{2} \leq 40 \%$, between $30-60 \%$, between $50-75 \%$ and $\geq 75 \%$ indicated low, moderate, substantial, and considerable heterogeneity, respectively. $\mathrm{P}$ values for $\mathrm{I}^{2}$ statistic were derived from the chi-square distribution of Cochran's $Q$ test. Together with the visual inspection of the forest plot, additional diagnostics were carried out to identify outlying or/and influential studies. Firstly, studies with studentized deleted residuals greater than 1.96 or less than -1.96 were identified as potential outliers [29]. Next, a set of leave-one-out analysis was performed to identify potential influential studies that resulted in a large change in the pooled estimates after they were left out one at a time from all studies. Lastly, a Baujat plot was used to identify studies that had high contributions to the heterogeneity in the meta-analytic data [30]. With these diagnostics, an agreement was made between two investigators to identify and remove outlying/influential studies. A funnel plot and Egger's tests was conducted to assess for reporting publication bias. Univariate meta regression analysis was also conducted on pre-ECMO characteristics where at least 4 data points were available. The analyses were conducted using the R Studio (Version 3.6.1, R Studio, Inc. Boston) using the 'metafor' and 'meta' packages.

\section{Results}

Of the 2054 articles screened, we identified 23 observational studies for systematic review and meta-analysis [3, 14, 15, 17, 31-48] (Table 1 and Additional file 1: Fig. 1); fifteen articles had overlapping information. Ten articles (6 from Australia, 1 from UK, 1 from Taiwan, 1 from USA, and 1 Multi regional) were excluded from the meta-analysis to best represent the population in terms of the period of study and setting, with minimal data loss and overlap. The definition of sepsis and septic shock was variable; most centers followed institutional or international guidelines to define criteria for ECMO initiation. Characteristics of the 13 retrospective studies included in the meta-analysis are summarized in Additional file 1: eTables 2, 3, and 4. The number of patients ranged from 7 to 1358 per study.

\section{Primary outcome}

Thirteen studies (Additional file 1: eTable 2) reported 2559 paediatric and neonatal patients with sepsis who needed ECMO support. The overall pooled estimate of survival in the cohort was 59\% (95\%CI: $51 \%$ to $67 \%$, $\mathrm{p}<0.01$ ) (Fig. 1). There was considerable heterogeneity amongst the studies; we identified three studies [31, 32, 46] that were outliers or influential with the leave one out analysis and the Baujat plot. After excluding the three studies, the remaining 10 studies had 2486 patients with a cumulative pooled estimate survival of 55\% (95\% CI $49 \%$ to $62 \%, \mathrm{p}<0.01$ ) (Additional file 1: Fig. 2 ).

\section{Secondary outcomes}

Children (0-18 years) with sepsis needing ECMO support had a median length of hospital stay of 28.8 days (IQR: 13-35.5 days), a median ICU stay of 13.5 days (IQR: 9.75-26.3 days), and a median ECMO duration of $129 \mathrm{~h}$ (IQR: 86.3-203.8 h). Three studies reported on the duration of ICU care prior to ECMO initiation which was $34 \mathrm{~h}$ (IQR: 8-96), $12 \mathrm{~h}$ (SD 13.4) and $7 \mathrm{~h}$, respectively. Two studies $[15,44]$ reported on duration of septic shock before ECMO which was $29.5 \mathrm{~h}$ (IQR: 20-46) and $22 \mathrm{~h}$ (IQR: 6.5-38) respectively.

\section{Subgroup analysis}

The pooled survival in each region was 73\% (95\% CI: 60\% to $85 \%, \mathrm{p}<0.01)(\mathrm{n}=2306)$ in North America, $48 \%(95 \%$ CI: $36 \%$ to $61 \%, \mathrm{p}=0.04)(\mathrm{n}=199)$ in Australasia and $52 \%$ (95\% CI: $38 \%$ to $66 \%, p=0.58)(n=54)$ in Europe. (Additional file 1: Figs. 3,4,5).

Use of venoarterial ECMO was identified in 9 studies with 208 patients $(95 \% \mathrm{CI}$ : $50 \%$ to $80 \%, \mathrm{p}<0.01)$ and a cumulative survival of 65\%. (Fig. 2) 9 of these patients were initially started with venoarterial ECMO and had 
Table 1 List of 23 articles included in systemic review and meta-analysis that reported on children with sepsis needing ECMO

\begin{tabular}{|c|c|c|c|c|c|c|}
\hline S2tudy author & Year & Sample Size & $\begin{array}{l}\text { Age (mean/ } \\
\text { median), (IQR, } \\
\text { SD) }\end{array}$ & $\%$ male & Type of ECMO & Country/location \\
\hline C.W. Lillehei et al & 1989 & 8 & Not Stated & Not Stated & Not Specified & USA (Children's Hospital Boston) \\
\hline S. McCune et al & 1990 & 10 & 80 hrs (37) & Not Stated & 10VA & USA (Children's National Medical Center) \\
\hline J. R. Hocker et al & 1992 & 15 & Not Stated & Not Stated & Not Specified & USA (Kosair Children's Hospital) \\
\hline D. Cochrane et al & 1992 & 5 & Not Stated & Not stated & $5 \mathrm{VA}$ & Australia (The Royal Children's Hospital) \\
\hline M. Nagaya et al & 1993 & 7 & $0.74 y(0.7-0.8)$ & Not Stated & $7 \mathrm{VA}$ & Japan (Central Hospital, Aichi) \\
\hline J. Beca and W. Butt & 1994 & 9 & $12 y(0.2-15)$ & 56 & $9 \mathrm{VA}$ & Australia (The Royal Children's Hospital) \\
\hline A.P. Goldman et al & 1997 & 12 & Not Stated & Not Stated & 10VA, 2VV & Multi-center (Australia and UK) \\
\hline D. K. Luyt et al & 2004 & 11 & $1 y(0.8-1.3)$ & Not Stated & $7 \mathrm{VA}, 4 \mathrm{~V}$ & UK (Glenfield Hospital, Leicester) \\
\hline G. MacLaren et al & 2007 & 45 & $2.5 y(0.4-9)$ & 62 & $45 \mathrm{VA}$ & Australia (The Royal Children's Hospital) \\
\hline R. Tiruvoipati et al & 2007 & 6 & $4 y(0.17-14)$ & Not stated & $2 \mathrm{VA}, 4 \mathrm{VV}$ & UK (Glenfield Hospital, Leicester) \\
\hline S. J.Wu et al & 2007 & 8 & $4.3 y(2.9-63)$ & 50 & $5 \mathrm{VA}, 3 \mathrm{VV}$ & Taiwan (Mackay Memorial Hospital) \\
\hline S. Horton et al & 2010 & 47 & $\begin{array}{l}1.4 y(0.1-7.5) \\
3.9 y(0.5-12.8)\end{array}$ & $\begin{array}{l}63 \\
67\end{array}$ & $\begin{array}{l}35 \text { Peripheral VA } \\
12 \text { Central VA }\end{array}$ & Australia (The Royal Children's Hospital) \\
\hline G. MacLaren et al & 2011 & 23 & $6 y(2.8-12.3)$ & 57 & 23 Central VA & Australia (The Royal Children's Hospital) \\
\hline C. C. Peng et al & 2012 & 12 & $4.7 y(3.1)$ & 58 & $8 \mathrm{VA}, 4 \mathrm{VV}$ & Taiwan (Mackay Memorial Hospital) \\
\hline Y. Kawai et al & 2015 & 14 & $12 y(4.2-15)$ & 64 & $13 \mathrm{VA}, 1 \mathrm{~W}$ & USA (University of Michigan) \\
\hline J. Rambaud et al & 2015 & 22 & $2.5 y(3.1)$ & 64 & $22 \mathrm{VA}$ & France (Armand-Trousseau Hospital) \\
\hline A. Ruth et al & 2015 & 1,858 & $1.1 y(0.2-6.7)^{1}$ & 53 & Not Specified & USA (Pediatric healthcare information system) \\
\hline K. Y. Chen et al & 2016 & 7 & $\begin{array}{l}3.9 y(0.4-12.8)^{2} \\
\text { Not Stated }\end{array}$ & Not Stated & Not Stated & $\begin{array}{l}\text { Australia (Royal Children's Hospital and Monash Medical } \\
\text { Center) }\end{array}$ \\
\hline A. Sole et al & 2018 & 21 & $\begin{array}{l}3.3 y(0.7-4.7) P \\
1 \text { day }(1-5) \mathrm{N}\end{array}$ & 62 & $21 \mathrm{VA}$ & Spain (Hospital Sant Joan de Deu) \\
\hline F. Oberender et al & 2018 & 44 & $3.6 y(0.5-8.0)$ & 52 & $44 \mathrm{VA}$ & Australia, New Zealand, Netherlands, UK, USA \\
\hline T. H. Chang et al & 2018 & 55 & $7.2 y(6.2)$ & 53 & Not Specified & Taiwan (National Taiwan University Children's Hospital) \\
\hline K. Robb et al & 2019 & 415 & Not Stated & Not stated & Not specified & USA (National Inpatient Sample) \\
\hline L.J. Schlapbach et al & 2019 & 80 & $1.3 y(0.1-7.0)$ & 61 & $\begin{array}{l}23 \text { Peripheral VA } \\
57 \text { Central VA }\end{array}$ & Australia \& New Zealand (ANZPIC Registry) \\
\hline
\end{tabular}

Abbreviations: VA: Venoarterial, VV: Venovenous, Peripheral and Central refers to the type of cannulation for ECMO. P: pediatric Patients, N: Neonates, Data presented as mean \pm SD, median (25th to 75th percentile), or median [range]. 1: Patients with ECMO-Only. 2 Patients with ECMO + RRT

\section{Study}

C.W. Lillehei et al. 1989

S. McCune et al. 1990

J.R. Hocker et al. 1992

M. Nagaya et al. 1993

D. K. Luyt et al. 2004

G. MacLaren et al. 2007

C. C. Peng et al. 2012

J. Rambaud et al. 2015

A. Ruth et al. 2015

A. Sole et al. 2018

T. H. Chang et al. 2018

K. Robb et al. 2019

L.J. Schlapbach et al. 2019

Total(Random Effects, 95\% Cl)

Heterogeneity: $\mathrm{Tau}^{2}=0.0108 ; \mathrm{Chi}^{2}=61.74, \mathrm{df}=12(\mathrm{P}<0.01) ; \mathrm{I}^{2}=81 \%$
Survivors Total Weight Survival(Proportion[95\% Cl])

$\begin{array}{rrrr}8 & 8 & 3.9 \% & 1.00[0.63 ; 1.00] \\ 10 & 10 & 4.5 \% & 1.00[0.69 ; 1.00] \\ 13 & 15 & 5.8 \% & 0.87[0.60 ; 0.98] \\ 5 & 7 & 3.5 \% & 0.71[0.29 ; 0.96] \\ 6 & 11 & 4.8 \% & 0.55[0.23 ; 0.83] \\ 21 & 45 & 9.5 \% & 0.47[0.32 ; 0.62] \\ 7 & 12 & 5.0 \% & 0.58[0.28 ; 0.85] \\ 13 & 22 & 7.1 \% & 0.59[0.36 ; 0.79] \\ 919 & 1858 & 14.2 \% & 0.49[0.47 ; 0.52] \\ 9 & 21 & 6.9 \% & 0.43[0.22 ; 0.66] \\ 17 & 55 & 10.1 \% & 0.31[0.19 ; 0.45] \\ 245 & 415 & 13.6 \% & 0.59[0.54 ; 0.64] \\ 44 & 80 & 11.1 \% & 0.55[0.43 ; 0.66]\end{array}$

$0.59[0.51 ; 0.67]$

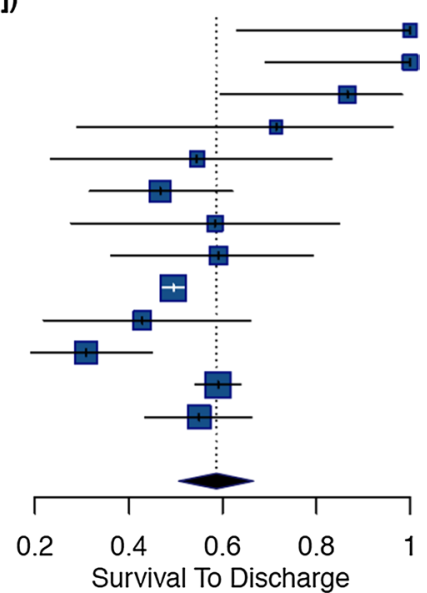

Fig. 1 Forest plot of studies reporting on use of ECMO in children with sepsis 


\section{Study}

C.W. Lillehei et al. 1989

S. McCune et al. 1990

M. Nagaya et al. 1993

D. K. Luyt et al. 2004

G. MacLaren et al. 2007

C. C. Peng et al. 2012

J. Rambaud et al. 2015

A. Sole et al. 2018

L.J. Schlapbach et al. 2019

Total(Random Effects, 95\% Cl)

Heterogeneity: $\operatorname{Tau}^{2}=0.0339 ; \mathrm{Chi}^{2}=30.50, \mathrm{df}=8(\mathrm{P}<0.01) ; \mathrm{I}^{2}=74 \%$

$208100.0 \%$
Survivors Total Weight Survival(Proportion [95\% Cl])

$\begin{array}{llll}8 & 8 & 9.0 \% & 1.00[0.63 ; 1.00]\end{array}$

$\begin{array}{llll}10 & 10 & 9.9 \% & 1.00[0.69 ; 1.00]\end{array}$

$\begin{array}{llll}5 & 7 & 8.5 \% & 0.71[0.29 ; 0.96]\end{array}$

$2 \quad 7 \quad 8.5 \% \quad 0.29[0.04 ; 0.71]$

$21 \quad 45 \quad 14.5 \% \quad 0.47[0.32 ; 0.62]$

$\begin{array}{llll}6 & 8 & 9.0 \% & 0.75[0.35 ; 0.97]\end{array}$

$\begin{array}{llll}13 & 22 & 12.7 \% & 0.59[0.36 ; 0.79]\end{array}$

$921 \quad 12.5 \% \quad 0.43[0.22 ; 0.66]$

$44 \quad 80 \quad 15.4 \% \quad 0.55[0.43 ; 0.66]$

$0.65[0.50 ; 0.80]$

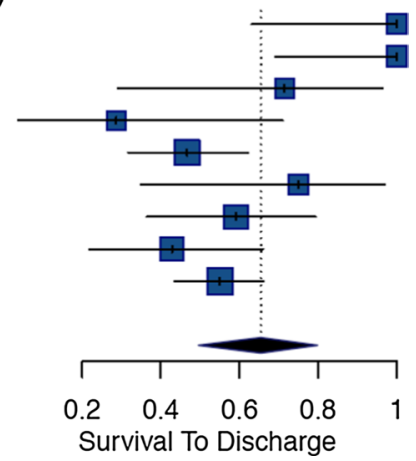

Fig. 2 Forest plot of studies reporting on use of Venoarterial ECMO in children with sepsis

\section{Study}

D. K. Luyt et al. 2004

G. MacLaren et al. 2007

C. C. Peng et al. 2012

J. Rambaud et al. 2015

A. Sole et al. 2018

L.J. Schlapbach et al. 2019

Total(Random Effects, $95 \% \mathrm{Cl}$ )

Heterogeneity: Tau $^{2}=0 ; \mathrm{Chi}^{2}=2.31, \mathrm{df}=5(\mathrm{P}=0.81) ; \mathrm{I}^{2}=0 \%$

Fig. 3 Forest plot of Pediatric group of patients needing ECMO in sepsis
Survivors Total Weight Survival(Proportion $[95 \% \mathrm{Cl}]$ )

$\begin{array}{llll}6 & 11 & 8.2 \% & 0.55[0.23 ; 0.83]\end{array}$

$\begin{array}{llll}17 & 39 & 28.0 \% & 0.44[0.28 ; 0.60]\end{array}$

$\begin{array}{llll}7 & 12 & 8.9 \% & 0.58[0.28 ; 0.85]\end{array}$

$\begin{array}{llll}4 & 8 & 6.0 \% & 0.50[0.16 ; 0.84]\end{array}$

$\begin{array}{llll}3 & 9 & 6.7 \% & 0.33[0.07 ; 0.70]\end{array}$

$\begin{array}{llll}32 & 59 & 42.2 \% & 0.54[0.41 ; 0.67]\end{array}$

$0.50[0.41 ; 0.59]$

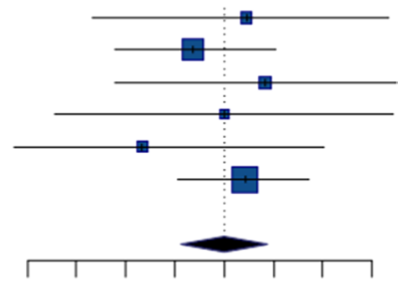

$\begin{array}{llllllll}0.1 & 0.2 & 0.3 & 0.4 & 0.5 & 0.6 & 0.7 & 0.8\end{array}$ Survival To Discharge been switched to venovenous ECMO during the ECMO run. After removal of 2 potential outliers [31,32], analysis of the remaining 7 studies yielded a pooled survival rate of $53 \%$ ( $95 \%$ CI: $45 \%$ to $60 \%, p=0.46$ ). (Additional file 1 : Fig. 6).

6 studies presented data on 138 pediatric patients aged between 28 days and 18 years with an overall pooled survival of $50 \%$ ( $95 \%$ CI: $41 \%$ to $59 \%$, p $=0.81$ ) (Fig. 3). 7 studies reported on 85 neonates with septic shock needing ECMO; overall pooled survival rate was 73\% (95\% CI: $56 \%$ to $87 \%, \mathrm{p}=0.03)$. After removal of 1 outlier study [32], 6 studies reported on 75 neonates with an overall pooled survival of $66 \%$ ( $95 \% \mathrm{CI}: 54 \%$ to $77 \%, \mathrm{p}=0.41$ ) (Additional file 1: Fig. 7a and b).

Univariate meta regression analysis was also conducted on pre-ECMO characteristics where at least 4 data points were available: there was no significant association found between survival and pre-ECMO lactate levels, Cardiac Arrest (\%), need for renal replacement therapy (\%), ECMO duration, overall length of stay in hospital and overall length of stay in ICU. (Table 2) (Additional file 1: Figs. 8-13).

Data on use of central ECMO and survival to discharge was reported in 3 studies from Australia/
Table 2 Meta-regression table of Potential Modifiers

\begin{tabular}{llll}
\hline Risk factors studied & No. of studies & P-value & $\begin{array}{l}\text { regression } \\
\text { coefficient } \\
{[\boldsymbol{\beta}]}\end{array}$ \\
\hline $\begin{array}{l}\text { Hospital Length of Stay } \\
\text { ICU Length of Stay }\end{array}$ & 5 & 0.87 & -0.0009 \\
$\begin{array}{l}\text { Pre-ECMO Factors } \\
\text { CPR }\end{array}$ & 6 & 0.73 & -0.0009 \\
$\begin{array}{l}\text { \% Renal Replacement Therapy } \\
\text { Lactate }\end{array}$ & 5 & 0.51 & -0.0025 \\
$\begin{array}{l}\text { ECMO Factors } \\
\text { ECMO duration }\end{array}$ & 4 & 0.77 & 0.0003 \\
\hline & 8 & 0.89 & -0.0019 \\
\hline
\end{tabular}

New Zealand. Horton et al. $(\mathrm{n}=12)$, MacLaren et al. $(\mathrm{n}=23)$ and Schlapbach et al. $(\mathrm{n}=57)$ reported a survival rate of $75 \%, 73 \%$ and $61 \%$ respectively for pediatric patients with septic shock who had atrio-aortic cannulation. The papers published by Horton et al. and MacLaren et al. were from the same institution with slightly overlapping time periods. 


\section{Complications}

A total of 23 studies (Additional file 1: Table 2) which included overlapping studies and studies included in the meta-analysis were used in descriptive analysis of other outcomes. 14 studies presented data on complications from a total of 246 patients. The pooled rate of complications was $31 \%$ (95\% CI: $19 \%$ to $44 \%$ ); out of 67 reported complications, $40(60 \%)$ were hemorrhagic, $14(21 \%)$ were neurologic, 8 (12\%) were vascular, $3(5 \%)$ were renal, 1 (1\%) was cardiovascular and $1(1 \%)$ was infectious. 6 studies reported data on mechanical and circuit complications (e.g. circuit clotting, oxygenation failures, pump and heat exchanger malfunction and air in circuits) with a pooled complication rate of $46 \%$ (95\% CI: $31 \%-62 \%)$.

\section{Microbiological etiology}

13 studies $(\mathrm{n}=316)$ reported on the microbiological etiology of sepsis. Out of the 258 organisms cultured, gram positive organisms accounted for $47 \%(n=121)$, followed by gram negative organisms at $38 \%(n=99)$, viral infections at $14 \%(\mathrm{n}=35)$ and fungal infections $1 \%(\mathrm{n}=3)$. Neisseria meningitidis, Staphylococcus aureus, and Streptococcus pneumoniae were the most common organisms isolated.

\section{Risk of bias}

All of the 13 studies that were assessed through the JBI checklist were good quality with minimum high score of $8 / 9$ with no concerns on risk of bias. Egger's test and funnel plots showed some evidence of publication bias in the total ECMO group which was resolved after removal of influential studies (Additional file 1: Fig. 14). There was no evidence of publication bias in the VA-ECMO, pediatric ECMO and neonatal ECMO groups: Additional file 1: Figs. 15, 16, 17 respectively) (Additional file 1: eTable 5). The GRADE system showed high level of certainty in the use of ECMO in pediatric and neonatal and venoarterial ECMO groups and a moderate level of certainty in the overall use of ECMO in children with sepsis (Table 3).

\section{Discussion}

The use of ECMO in pediatric sepsis has increased over the past decade [49] with variable survival rates [49-51]. Our meta-analysis of observational studies showed that overall survival rates of children with sepsis treated with ECMO were $59 \%$. Neonates had higher survival rates (73\%). Gram positive organisms were the most common type of pathogen.

The hemodynamic manifestations of septic shock can vary between different age groups. While early-onset sepsis may present predominantly as right heart dysfunction from persistent pulmonary hypertension of the newborn (PPHN), older infants and young children often manifest severe left ventricular dysfunction. Older children and adults more commonly present with distributive shock [15]. The role of ECMO in the management of refractory septic shock in neonates and children stems by virtue of its ability to provide perfusion of oxygenated blood to tissues and maintain gas exchange even in refractory cardiopulmonary failure. However, the specific threshold as to when shock, or multi-organ dysfunction should be considered "refractory", remains poorly defined. Some data indicate that venoarterial ECMO is associated with better survival than conventional therapy in children with septic shock if high ECMO flows (> $150 \mathrm{~mL} / \mathrm{kg} / \mathrm{min}$ ) can be provided [20,45]. While data on ECMO flows were not available in all the studies included in this metaanalysis, our analysis of neonatal and pediatric septic patients who needed venoarterial (VA) ECMO showed an overall pooled survival of $63 \%$; subsequent removal of outlier studies yielded an overall pooled survival of $53 \%$. Children who underwent central ECMO cannulation have been shown to have survival rates up to $73 \%$ in single centre studies [17]. In comparison, the ELSO registry reported survival rates for pediatric patients with sepsis supported on ECMO of 52\% [49].

The American College of Critical Care Medicine guidelines for hemodynamic support of pediatric and neonatal septic shock recommends ECMO as the therapy of choice for newborn patients with refractory PPHN and sepsis with Level $1 \mathrm{C}$ evidence; however the guidelines highlight an expected survival with ECMO for septic shock being no greater than $50 \%$ in children, with Level $2 \mathrm{C}$ evidence for consideration of ECMO in this group [18]. The recently published Surviving Sepsis Campaign International Guidelines in children suggested venovenous ECMO for children with sepsis induced respiratory distress syndrome and refractory hypoxia as well as venoarterial ECMO as a rescue therapy in children with septic shock refractory to all other treatments. The recommendations for both above were weak based on very low quality of evidence [20]. Our meta-analysis supplement the above recommendations and showed survival rates above $50 \%$ in septic children and more than $70 \%$ in neonatal sepsis with moderate to high level of certainty in the level of evidence.

There are several limitations to the study. This review is based on non-randomized or non-propensity-matched studies, and the studies selected for analysis showed moderate heterogeneity. The challenges of interpreting the heterogeneity using I 2 values has been highlighted when studies with large sample sizes result in very narrow confidence intervals. It has also been established that I 2 for the pooled estimate can be high even in the presence of modest inconsistency and can be misleading [52]. Inter-center practice variability, patient selection, 


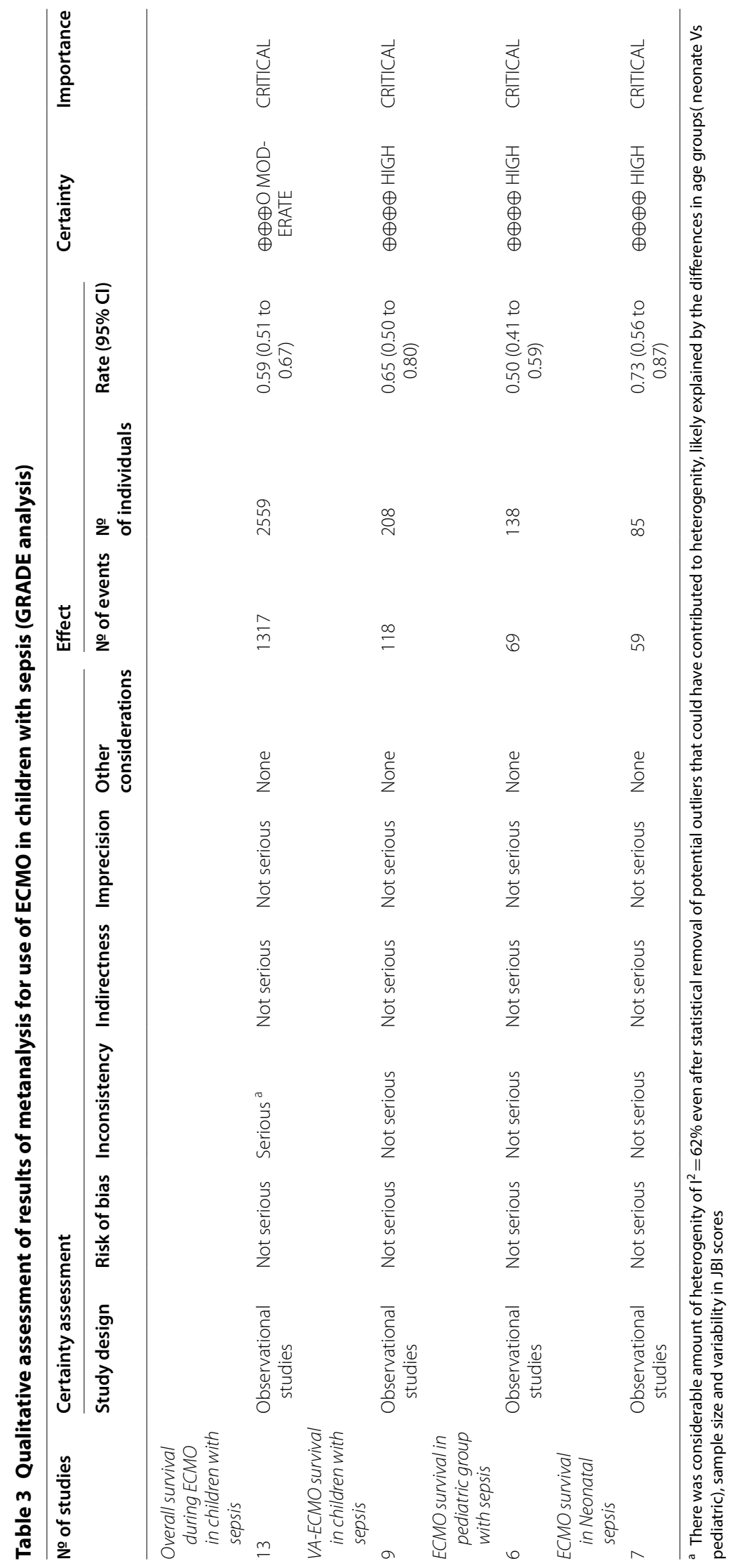


sample sizes and reporting patterns likely add to the heterogeneity in our cohort. The results obtained should be interpreted in light of this heterogeneity; even if the heterogeneity was accounted for via use of the randomeffects model [53-55]. The diagnostic criteria of refractory septic shock varied between studies, only a handful of studies reported the use of the 2005 pediatric Sepsis Consensus Conference Criteria [56] while some reported using the International Classification of Diseases (ICD-9) to define septic shock and most of the papers diagnosed septic shock based on their institutional guidelines. An international multicentre study based on a Delphi process followed by data-driven derivation and validation defined refractory septic shock in children as the combination of severe cardiovascular dysfunction (measured by poor cardiac function and/or preceding cardiac arrest), high lactate, and high vasopressor requirements (measured by vasopressor-inotrope score) [11]. Unfortunately, the data provided in the studies included in this metanalysis would not allow to verify if the proposed refractory septic shock criteria were met. The timing of ECMO initiation in children with sepsis could not be assessed with certainty from the literature, although one recent multicentre cohort study concluded that ECMO was only of benefit if the predicted risk of death was $>50 \%$ (48). The studies included in our analysis spanned from 1992 to 2020, where sepsis diagnosis, sepsis management, ECMO technology and ECMO practice have undergone substantial changes. Also, meta-regression analyses are inherently constrained by a lack of power, resulting in an increased risk of Type 2 errors suggesting that lack of significant association does not imply that a correlation does not exist [57]. However, this remains the largest available cohort of patients which has been analysed so far; there was no evidence of publication bias and the methodological quality of all the studies included in our analysis scored high (>8/9), using the JBI critical appraisal tool (Additional file 1: Table 6). The GRADE analysis demonstrated moderate to high certainty in the evidence presented in this paper.

\section{Conclusion}

The use of ECMO to resuscitate and support children with sepsis and refractory shock is feasible and is associated with survival rates as high as $59 \%$. Neonates had higher survival rates and central cannulation may be associated with better outcomes in children needing ECMO with sepsis. Despite the limitations of studies included in this metanalysis, the aggregate data indicate that survival for patients treated with septic shock overall justifies recommendation to consider ECMO in refractory septic shock for all pediatric age groups. Future studies should provide more evidence to inform on timing and thresholds for ECMO initiation, including dynamic assessment of response to therapy/deterioration.

\section{Supplementary information}

Supplementary information accompanies this paper at https://doi. org/10.1186/s13054-020-03418-z.

Additional file 1. Supplementary file containing additional figures (Supplementary figures 1-17) andtables( Supplementary tables 1-7)

\section{Acknowledgements}

We acknowledge Ms. Suei Nee of the medical library at the Yong Loo Lin School of Medicine (YLLSOM) and Ryan Ling at the YLLSOM.

\section{Authors' contributions}

Concept and design: KR, GM. PROSPERO registration: KR, NY. Data collection: NY. KR. Data analysis: NY, TCS. Data interpretation: NY, TCS,KR. Manuscript write up: KR. Tables and Figures: NY. Manuscript editing: GM, LS, PA, LR, LS, RB. Manuscript formatting: KR. All authors read and approved the final manuscript.

Funding

LS is supported by a NHMRC Practitioner Fellowship and by the Children's Hospital Foundation, Brisbane, Australia.

\section{Availability of supporting data \\ Available.}

\section{Ethics approval and consent to participate} NA.

\section{Consent for publication}

NA.

\section{Competing interests}

The authors have no conflict of interest to disclose.

\section{Author details}

${ }^{1}$ Cardiothoracic Intensive Care Unit, Department of Cardiothoracic Surgery, National University Hospital, Singapore 119228, Singapore. ${ }^{2}$ Yong Loo Lin School of Medicine, National University of Singapore, Singapore, Singapore. ${ }^{3}$ Queen's University Belfast School of Medicine, Belfast, UK. ${ }^{4}$ Department of Cardiology, Boston Children's Hospital, Boston, MA, USA. ${ }^{5}$ Department of Pediatrics, Harvard Medical School, Boston, MA, USA. ${ }^{6}$ University of Texas Southwestern Medical Center, Dallas, USA. ${ }^{7}$ Division of Pediatric Critical Care Medicine, University of Michigan, Ann Arbor, USA. ${ }^{8}$ Department of Intensive Care Medicine and Neonatology, and Children's Research Center,University Children's Hospital of Zurich, University of Zurich, Zurich, Switzerland. ${ }^{9}$ Pediatric Critical Care Research Group, Child Health Research Centre, The University of Queensland and Queensland Children's Hospital, Brisbane, QLD, Australia.

Received: 9 August 2020 Accepted: 30 November 2020 Published online: 07 December 2020

\section{References}

1. Fleischmann-Struzek C, Goldfarb DM, Schlattmann P, Schlapbach LJ, Reinhart K, Kissoon N. The global burden of paediatric and neonatal sepsis: a systematic review. Lancet Respir Med. 2018;6(3):223-30.

2. Schlapbach $L$, Kissoon N. Defining pediatric sepsis. JAMA Pediatr. 2018;172(4):312-4.

3. Rambaud J, Guellec I, Leger PL, Renolleau S, Guilbert J. Venoarterial extracorporeal membrane oxygenation support for neonatal and pediatric refractory septic shock. Indian J Crit Care Med. 2015;19(10):600-5.

4. Reinhart K, Daniels R, Kissoon N, Machado FR, Schachter RD, Finfer S. Recognizing sepsis as a global health priority: a WHO resolution. N Engl J Med. 2017:377(5):414-7. 
5. Rudd KE, Johnson SC, Agesa KM, Shackelford KA, Tsoi D, Kievlan DR, Colombara DV, Ikuta KS, Kissoon N, Finfer S, et al. Global, regional, and national sepsis incidence and mortality, 1990-2017: analysis for the Global Burden of Disease Study. Lancet. 2020;395(10219):200-11.

6. Tan B, Wong JJ, Sultana R, Koh J, Jit M, Mok YH, Lee JH. Global case-fatality rates in pediatric severe sepsis and septic shock: a systematic review and meta-analysis. JAMA Pediatr. 2019:173(4):352-62.

7. Evans IVR, Phillips GS, Alpern ER, Angus DC, Friedrich ME, Kissoon N, Lemeshow S, Levy MM, Parker MM, Terry KM, et al. Association between the New York sepsis care mandate and in-hospital mortality for pediatric sepsis. JAMA. 2018;320(4):358-67.

8. Schlapbach LJ, Straney L, Alexander J, MacLaren G, Festa M, Schibler A, Slater A, Group APS. Mortality related to invasive infections, sepsis, and septic shock in critically ill children in Australia and New Zealand, 2002-13: a multicentre retrospective cohort study. Lancet Infect Dis. 2015:15(1):46-54

9. Leclerc F, Leteurtre S, Duhamel A, Grandbastien B, Proulx F, Martinot A, Gauvin F, Hubert P, Lacroix J. Cumulative influence of organ dysfunctions and septic state on mortality of critically ill children. Am J Respir Crit Care Med. 2005:171(4):348-53.

10. Watson RS, Carcillo JA. Scope and epidemiology of pediatric sepsis. Pediatr Crit Care Med. 2005;6(3 Suppl):S3-5

11. Morin L, Ray S, Wilson C, Remy S, Benissa MR, Jansen NJG, Javouhey E, Peters MJ, Kneyber M, De Luca D, et al. Refractory septic shock in children: a European Society of Paediatric and Neonatal Intensive Care definition. Intensive Care Med. 2016;42(12):1948-57.

12. Brierley J, Carcillo JA, Choong K, Cornell T, Decaen A, Deymann A, Doctor A, Davis A, Duff J, Dugas MA, et al. Clinical practice parameters for hemodynamic support of pediatric and neonatal septic shock: 2007 update from the American College of Critical Care Medicine. Crit Care Med. 2009:37(2):666-88.

13. Dellinger RP, Levy MM, Rhodes A, Annane D, Gerlach H, Opal SM, Sevransky JE, Sprung CL, Douglas IS, Jaeschke R, et al. Surviving Sepsis Campaign: international guidelines for management of severe sepsis and septic shock, 2012. Intensive Care Med. 2013;39(2):165-228.

14. Ruth A, McCracken CE, Fortenberry JD, Hebbar KB. Extracorporeal therapies in pediatric severe sepsis: findings from the pediatric health-care information system. Crit Care. 2015;19:397.

15. MacLaren G, Butt W, Best D, Donath S, Taylor A. Extracorporeal membrane oxygenation for refractory septic shock in children: one institution's experience. Pediatr Crit Care Med. 2007;8(5):447-51.

16. Bartlett RH. Extracorporeal support for septic shock. Pediatr Crit Care Med. 2007:8(5):498-9.

17. MacLaren G, Butt W, Best D, Donath S. Central extracorporeal membrane oxygenation for refractory pediatric septic shock. Pediatr Crit Care Med. 2011;12(2):133-6.

18. Davis AL, Carcillo JA, Aneja RK, Deymann AJ, Lin JC, Nguyen TC, Okhuysen-Cawley RS, Relvas MS, Rozenfeld RA, Skippen PW, et al. American college of critical care medicine clinical practice parameters for hemodynamic support of pediatric and neonatal septic shock. Crit Care Med. 2017:45(6):1061-93.

19. Schlapbach LJ, Chatfield MD, Rycus P, MacLaren G. Extracorporeal membrane oxygenation for group B streptococcal sepsis in neonates: a retrospective study of the extracorporeal life support organization registry. Pediatr Crit Care Med. 2020;21:505.

20. Weiss SL, Peters MJ, Alhazzani W, Agus MSD, Flori HR, Inwald DP, Nadel S, Schlapbach LJ, Tasker RC, Argent AC, et al. Surviving sepsis campaign international guidelines for the management of septic shock and sepsis-associated organ dysfunction in children. Pediatr Crit Care Med. 2020;21(2):e52-106.

21. MacLaren G, Butt, W.: ECMO for septic shock. Ann Arbor, MI: ELSO-Extracorporeal Life Support Organization; 2018.

22. Liberati A, Altman DG, Tetzlaff J, Mulrow C, Gotzsche PC, loannidis JP, Clarke M, Devereaux PJ, Kleijnen J, Moher D. The PRISMA statement for reporting systematic reviews and meta-analyses of studies that evaluate healthcare interventions: explanation and elaboration. BMJ. 2009;339:b2700

23. Munn Z, Moola S, Riitano D, Lisy K. The development of a critical appraisal tool for use in systematic reviews addressing questions of prevalence. Int J Health Policy Manag. 2014;3(3):123-8.
24. Guyatt GH, Oxman AD, Schunemann HJ, Tugwell P, Knottnerus A. GRADE guidelines: a new series of articles in the Journal of Clinical Epidemiology. J Clin Epidemiol. 2011;64(4):380-2.

25. DerSimonian R, Laird N. Meta-analysis in clinical trials. Control Clin Trials. 1986 Sep 1;7(3):177-88.

26. Freeman MF, Tukey JW. Transformations related to the angular and the square root. Ann Math Stat. 1950 Dec;1:607-11.

27. Miller JJ. The inverse of the Freeman-Tukey double arcsine transformation. Am Stat. 1978;32(4):138.

28. Wan X, Wang W, Liu J, Tong T. Estimating the sample mean and standard deviation from the sample size, median, range and/or interquartile range. BMC Med Res Methodol. 2014;14:135.

29. Viechtbauer W, Cheung MW. Outlier and influence diagnostics for metaanalysis. Res Synth Methods. 2010;1(2):112-25.

30. Baujat B, Mahe C, Pignon JP, Hill C. A graphical method for exploring heterogeneity in meta-analyses: application to a meta-analysis of 65 trials. Stat Med. 2002;21(18):2641-52.

31. Lillehei CW, O'Rourke PP, Vacanti JP, Crone RK. Role of extracorporeal membrane oxygenation in selected pediatric respiratory problems. J Thorac Cardiovasc Surg. 1989;98(5 Pt 2):968-70.

32. McCune S, Short BL, Miller MK, Lotze A, Anderson KD. Extracorporeal membrane oxygenation therapy in neonates with septic shock. J Pediatr Surg. 1990;25(5):479-82.

33. Hocker JR, Simpson PM, Rabalais GP, Stewart DL, Cook LN. Extracorporeal membrane oxygenation and early-onset group B streptococcal sepsis. Pediatrics. 1992;89(1):1-4.

34. Nagaya MTM, Futamura M. The efficacy of extracorporeal membrane oxygenation (ECMO) in newborns with septic shock. Pediatr Surg Int. 1993:8:298-302.

35. Beca J, Butt W. Extracorporeal membrane oxygenation for refractory septic shock in children. Pediatrics. 1994:93(5):726-9.

36. Goldman AP, Kerr SJ, Butt W, Marsh MJ, Murdoch IA, Paul T, Firmin RK, Tasker RC, Macrae DJ. Extracorporeal support for intractable cardiorespiratory failure due to meningococcal disease. Lancet. 1997;349(9050):466-9.

37. Luyt DK, Pridgeon J, Brown J, Peek G, Firmin R, Pandya HC. Extracorporeal life support for children with meningococcal septicaemia. Acta Paediatr. 2004;93(12):1608-11.

38. Tiruvoipati R, Moorthy T, Balasubramanian SK, Platt V, Peek GJ. Extracorporeal membrane oxygenation and extracorporeal albumin dialysis in pediatric patients with sepsis and multi-organ dysfunction syndrome. Int J Artif Organs. 2007;30(3):227-34.

39. Wu SJCM, Sun S, Li JY. Extracorporeal membrane oxygenation for acute respiratory distress syndrome: a single center experience. Acta Cardiol Sin. 2007;23(2):741.

40. Horton S, d'Udekem Y, Shann F, Butt W, Bennett M, Best D, Brizard C. Extracorporeal membrane oxygenation via sternotomy for circulatory shock. J Thorac Cardiovasc Surg. 2010;139(2):e12-13.

41. Peng CC, Wu SJ, Chen MR, Chiu NC, Chi H. Clinical experience of extracorporeal membrane oxygenation for acute respiratory distress syndrome associated with pneumonia in children. J Formos Med Assoc 2012;111(3):147-52.

42. Kawai Y, Cornell TT, Cooley EG, Beckman CN, Baldridge PK, Mottes TA, Luckritz KE, Plomaritas KS, Meade JM, Odetola FO, et al. Therapeutic plasma exchange may improve hemodynamics and organ failure among children with sepsis-induced multiple organ dysfunction syndrome receiving extracorporeal life support. Pediatr Crit Care Med. 2015:16(4):366-74.

43. Chen KY, Cheung M, Burgner DP, Curtis N. Toxic shock syndrome in Australian children. Arch Dis Child. 2016;101(8):736-40.

44. Sole A, Jordan I, Bobillo S, Moreno J, Balaguer M, Hernandez-Platero L, Segura S, Cambra FJ, Esteban E, Rodriguez-Fanjul J. Venoarterial extracorporeal membrane oxygenation support for neonatal and pediatric refractory septic shock: more than 15 years of learning. Eur J Pediatr. 2018;177(8):1191-200.

45. Oberender F, Ganeshalingham A, Fortenberry JD, Hobson MJ, Houmes RJ, Morris KP, Numa A, Hoq MM, Donath S, Beca J, et al. Venoarterial extracorporeal membrane oxygenation versus conventional therapy in severe pediatric septic shock. Pediatr Crit Care Med. 2018;19(10):965-72.

46. Chang TH, Wu ET, Lu CY, Huang SC, Yang TI, Wang CC, Chen JM, Lee PI, Huang LM, Chang LY. Pathogens and outcomes in pediatric septic shock 
patients supported by extracorporeal membrane oxygenation. J Microbiol Immunol Infect. 2018;51(3):385-91.

47. Robb K, Badheka A, Wang T, Rampa S, Allareddy V, Allareddy V. Use of extracorporeal membrane oxygenation and associated outcomes in children hospitalized for sepsis in the United States: A large populationbased study. PLOS ONE. 2019;14(4):e0215730.

48. Schlapbach LJ, Chiletti R, Straney L, Festa M, Alexander D, Butt W, MacLaren G, Australian,New Zealand Intensive Care Society Centre for $\mathrm{O}$, Resource $\mathrm{E}$, et al. Defining benefit threshold for extracorporeal membrane oxygenation in children with sepsis-a binational multicenter cohort study. Crit Care. 2019;23(1):429.

49. Barbaro RP, Paden ML, Guner YS, Raman L, Ryerson LM, Alexander P, Nasr VG, Bembea MM, Rycus PT, Thiagarajan RR, et al. Pediatric extracorporeal life support organization registry international report 2016. ASAIO J. 2017;63(4):456-63.

50. Skinner SC, locono JA, Ballard HO, Turner MD, Ward AN, Davenport $\mathrm{DL}$, Paden ML, Zwischenberger JB. Improved survival in venovenous vs venoarterial extracorporeal membrane oxygenation for pediatric noncardiac sepsis patients: a study of the Extracorporeal Life Support Organization registry. J Pediatr Surg. 2012;47(1):63-7.

51. Phillips MR, Khoury AL, Stephenson BJ, Edwards LJ, Charles AG, McLean SE. Outcomes of pediatric patients with abdominal sepsis requiring surgery and extracorporeal membrane oxygenation using the Extracorpor eal Life Support Organization database. Am Surg. 2015;81(3):245-51.

52. Iorio A, Spencer FA, Falavigna M, Alba C, Lang E, Burnand B, McGinn T, Hayden J, Williams K, Shea B, et al. Use of GRADE for assessment of evidence about prognosis: rating confidence in estimates of event rates in broad categories of patients. BMJ. 2015;350:h870.

53. Clarke MA, Long BJ, Del Mar MA, Arbyn M, Bakkum-Gamez JN, Wentzensen N. Association of endometrial cancer risk with postmenopausal bleeding in women: a systematic review and meta-analysis. JAMA Internal Medicine. 2018;178(9):1210-22.

54. Khoushhal Z, Hussain MA, Greco E, Mamdani M, Verma S, Rotstein O, Tricco AC, Al-Omran M. Prevalence and causes of attrition among surgical residents: a systematic review and meta-analysis. JAMA Surgery. 2017;152(3):265-72

55. ten Broek RPG, Issa Y, van Santbrink EJP, Bouvy ND, Kruitwagen RFPM, Jeekel J, Bakkum EA, Rovers MM, van Goor H. Burden of adhesions in abdominal and pelvic surgery: systematic review and met-analysis. BMJ. 2013;347:f5588.

56. Goldstein B, Giroir B, Randolph A, International Consensus Conference on Pediatric S. International pediatric sepsis consensus conference: definitions for sepsis and organ dysfunction in pediatrics. Pediatr Crit Care Med. 2005;6(1):2-8.

57. Hempel S, Miles JN, Booth MJ, Wang Z, Morton SC, Shekelle PG. Risk of bias: a simulation study of power to detect study-level moderator effects in meta-analysis. Syst Rev. 2013;2:107.

\section{Publisher's Note}

Springer Nature remains neutral with regard to jurisdictional claims in published maps and institutional affiliations.
Ready to submit your research? Choose BMC and benefit from:

- fast, convenient online submission

- thorough peer review by experienced researchers in your field

- rapid publication on acceptance

- support for research data, including large and complex data types

- gold Open Access which fosters wider collaboration and increased citations

- maximum visibility for your research: over $100 \mathrm{M}$ website views per year

At BMC, research is always in progress.

Learn more biomedcentral.com/submissions 